\title{
СТРУКТУРНИ ПРОМЕНИ НА СЕМЕЈСТВОТО: ПЕРЦЕПЦИИ ЗА НОВИ МОДЕЛИ НА СЕМЕЈНИ ЗАЕДНИЦИ ВО РЕПУБЛИКА СЕВЕРНА МАКЕДОНИЈА
}

\section{Кратка содржина}

Историските и демографски процеси влијаеле значително на трансформациијата на традиционалното во модерно семејство, при што ја промениле неговата структура, функции, партнерските односи, како и родителството и воспитуватето на децата, перцеепцијата за бракот, разводот, наталитетот итн. По индустриската револуција нуклеарната форма на семејство станува доминантен модел на семејство во Европа и е сѐ уште најзастапен и во македонското современо општество.

Општествени промени како глобализацијата, индивидулизацијата, секуларизацијата, како и динамиката на современото живеене довеле до нови форми на семејства кои се одраз на современите опитества. Во овој труд ќе биде претставена кратка анахиза на структурата на семејствата, трансформациијата од традиционално кон модерно семејство и новите модели на семејства. Конкретно ќе бидат подетално елаборирани вонбрачните заедници, мултиетничките семејства и истополовите заедниции во РС Македонија и ќе бидат презентирани резултатите од квалитативно истражуване за перцепцијата на овие модели на семејства во РС Македонија спроведено во текот на 2019 година.

Клучни зборови: МОДЕЛИ НА СЕМЕЈСТВО, ВОНБРАЧНИ ЗАЕДНИЦИ, МУЛТИЕТНИЧКИ СЕМЕЈСТВА, ИСТОПОЛОВИ ЗАЕДНИЦИ, РС МАКЕДОНИЈА

\section{Вовед}

Семејството, под заемно вдијание на општествени, демографски и историски процеси било секогаш подложно на промени и трансформации кои се однесуваат на неговата структура, функции, партнерски односи и односот на родителите кон децата. Иако традиционалното семејство со патријархален карактер и проширено во својата структура, карактеристично за прединдустриските општества, изгледа статично и непроменето, сепак и во минатото постоеле повеќе модели на семејства, особено кога станува збор за нивната структура, иако истите не биле многу застапени. Несомнено, по Индустриската револуција нуклеарната форма на семејство составено од родители и нивните деца станува доминантен модел на семеј- 
ство во Европа и е сѐ уште најзастапен и во македонското современо општество.

Општествените промени од втората подовина на 20-тиот век пак, како што се глобализацијата, секуларизацијата, ширењето и прифаќањето на феминистичките идеи, економската еманципација на жената, индивидуализацијата и други социјални процеси дополнително влијаеле на промената на структурата на семејството, бракот, разводот, наталитетот итн. Денес, дефиницијата за современото семејство треба да биде доволно широка за да може да ги опфати сите модели на семејни структури, нивните динамики и функции и токму затоа, повеќе не говориме за семејството во еднина туку за модели на семејства.

Во овој труд ќе биде презентирана кратка анализа на трансформацијата од традиционално кон модерно семејство со фокус на неговите структурни промени во Европа и на Балканот. Дополнително ќе бидат елаборирани модели на семејства во современото македонско општество со фокус на вонбрачните заедници, мултиетничките семејства и истополовите заедници. Конечно, ќе бидат презентирани резултатите од квалитативно истражување за перцепцијата на горенаведените модели на семејства во РС Македонија спроведено во текот на 2019 година.

\section{Од традиционално кон модерно семејство}

Најголемите структурни промени на европското семејство се забележани по Индустриската револуција, која започнала во Англија во средината на 18-тиот век, но на Балканскиот Полуостров и во РС Македонија пристигнала многу подоцна. Трансформацијата на традиционалното во модерно семејство се однесува пред сѐ на неговата нуклеарна форма, односно одвојување на децата од родитедите по бракот, предизвикано од процесите на индустријализација и урбанизација, како и зачестената миграција село - град. Сепак, мора да се забележи дека проширеното семејство опстојува на Балканот многу подолго и таква структура на семејства (родители и деца и нивните семејства, немажени и неженети браќа и сестри, односно роднини по хоризонтална и вертикална линија) се забележуваат и во текот на 20-тиот век.

Социолозите не се согласуваат секогаш за причините на транзицијата од традиционално кон модерно семејство. Според еволутивниот концепт на Фредерик Де Плеј, нуклеарната структура на семејството (родители и деца) во сите европски земји потекнува од поширокото семејство карактеристично за традиционалното прединдустриско општество. Социологот тврди дека индустријадизацијата, како и процесите на географска мобилност и урбанизација ги придвижиле младите во градовите во потрага по работа, со што се создала неминовно посебна семејна единица. Питер Ласлет, од друга страна, во своето истражување од 70-тите години од 20-тиот век тврди дека нуклеарното семејство било присутно во Англија 
уште од 16-тиот век, како рецидив на проширеното семејство кое преминувало во нуклеарно поради смртта на родитедите, која во тој период се случувала порано, бидејќ́ животниот век на луѓето бил пократок (Мицковиќ, 2008, 27-37).

Класификацијата на Питер Ааслет (Laslett, Wall, 1972) раздикува шест видови домаќинства во кои спаѓаат повеќе видови семејства:

1. Самечки домаќинства во кои живеат вдовец/вдовица иди маж/ жена без брачен статус.

2. Пуѓе кои живеат во исто домаќинство но според Даслет немаат "свое“ семејство: (а) немажени/неженети браќа и сестри кои живеат без родителите; (б) други видови роднини кои живеат заедно (братучеди, тетка и внука, баба и внук итн.); (в) луѓе кои не се во сродство (најчесто цимери).

3. Нуклеарни семејства, односно родители и нивните деца: (а) брачна двојка без деца; (б) брачна двојка со деца (в) вдовец со деца и (г) вдовица со деца.

4. Проширено семејство: (а) по вертикална нагорна динија: вкдучува родител (вдовец/вдовица) на мажот иди жената од нуклеарното семејство или роднина на родителите без брачен статус; (б) по вертикална надолна линија: вклучува немажени и неженети внуци; (в) по хоризонтална динија: вкдучува роднина без брачен статус на мажот или жената од нуклеарното семејство или деца на истите роднини и (г) комбинација на претходните три типа семејства.

5. Комплексни/многубројни семејства односно домаќинства во кои живеат повеќе брачни парови во блиско сродство: (а) втора единица по нагорна динија, на пр. брачен пар и родителите на сопругот или сопругата; (б) втора единица по надолна линија, на пр. брачен пар и дете со брачен партнер; (в) родител (вдовец/вдовица) и две или повеќе деца и нивните брачни партнери; (г) frereches - француски термин кој означува роднини кои живеат во исто домаќинство. Според Ласлет тоа е домаќинство кое има повеќе брачни парови, но не и нивни родител. (д) Други видови многубројни семејства.

6. Неопределено домаќинство.

Во РС Македонија и генерално на Балканот, транзицијата од традиционално кон модерно општество настанала многу подоцна од државите во Западна Европа. Балканските семејства, исто како и европските, опфаќале всушност мноштво форми на семејства, меѓу кои највпечатливи биле големите и комплексни домаќинства во кои живееле повеќегенерациски семејни заедници (задруги) кои опстанале на Балканскиот Полуостров до 20 век. Овие семејни заедници биле најзастапени во Централна и Северна Македонија, Босна и Херцеговина и Северозападна Бугарија и претставувале производно-потрошувачки домаќинства кои се занимавале со сточар- 
ство и земјоделство. Иако покомпдексни по структурата и системот на сродство, но раздични според организацијата на трудот и системот на наследство, овие семејни заедници најмногу одговараат на проширените и комплексните семејства со повеќе домаќинства според класификацијата на Ласлет (Wall, Harevan, Ehmer, Cerman, 2001, 242 - 256).

Покрај структурните трансформации, кај модерните семејства се забележуваат значителни промени на меѓусебните односи и функциите во рамките на семејство, партнерските односи и односот родитед - дете, меѓу кои најзначителни се: отфрлањето на примогенитурата како систем на наследство; зајакнати емоционални односи меѓу родителите и децата; поголема грижа на родителите за здравјето, исхраната, образованието и иднината на нивните деца; намалување на стапката на натадитет (научните и медицинските откритија ја намадиле високата стапка на смртност кај децата); појава на култот кон жената - мајка и сопруга (Мицковиќ, 2008).

Конечно, најзначајните промени на семејните односи и структури настануваат по револуциите на 60-тите (хипи-движење) и 70-тите години (феминизам) од 20-тиот век. Сѐ до активното учество на жената на пазарот на трудот, таа останала во домот во улога на домаќинка, негувателка на децата, сопруга и поддршка на мажот. Во Европа за време на Првата и на Втората светска војна, жените, во отсуство на мажите - војници, по потреба се вработувале во раздични сектори и станувале носители на економската функција во домот. Во меѓувоениот период тие повторно „се вратиле“" во домот, за по Втората светка војна и ширењето на феминистичките идеи да навлезат на пазарот на трудот подеднакво со мажите. Овие настани дополнително ја промениле структурата на семејството, бракот, партнерските односи и натадитет (Nazio, 2008), а со појавата на контрацептивните средства, жената започнала да ја контродира и репродуктивната функција. Со овие промени, бракот повеќе не претставува заедница за гарантирање финансиска стабилност на жената и децата и регулирање на сексуалните односи.

Несомнено, историските и демографски процеси најмногу влијаеле на трансформацијата на традиционалното во модерно семејство, при што значително ја промениле неговата структура, функции, партнерските односи, како и родителството и воспитувањето на децата, перцепцијата за бракот, разводот, наталитетот итн. Промените кои ги анализиравме во овој дел од трудот, како и општествените промени и динамиката на современото живеење довеле до нови форми на семејства кои се одраз на современите општества и ќе бидат елаборирани во следниот дел од трудот.

\section{Семејството во множина}

Ширењето на општествените процеси како глобализацијата, секуларизацијата, урбанизацијата, индустријализацијата и забрзаниот развој на технологиите придонесоа до трансформација на структурата и фун- 
кциите на семејството во РС Македонија кон крајот на 20-тиот и почетокот на 21-виот век. Денес, исто како и во минатото, не постои единствена дефиниција за семејството, туку зборуваме за модели на семејства во множина. Иако нуклеарното семејство и понатаму претставува доминантен модел на семејство во РСМ, сепак изминатите децении сведоци сме на оддалечувањето од традиционалните форми на семејства и партнерски односи и сѐ повеќе се застапени други модели на семејства, меѓу кои:

- вонбрачни заедници (семејства чии партнери не се во брак);

- семејства со самохрани родитеди (семејства составени од еден родител и едно или повеќе деца);

- реконструирани семејства (брачна двојка во која едниот или двајцата партнери имаат дете/деца од претходна врска иди брак);

- хомосексуални или истополови заедници (семејства чии партнери се од ист пОА);

- иселенички семејства (семејства кои ја напуштиле земјата на потекио);

- семејства посвоители (семејства со најмалку едно посвоено дете);

- згрижувачки семејства (семејства кои згрижуваат дете без родителска грижа, дете со пречки во развојот или одземено дете поради запоставување и здоупотреба).

- мултиетнички семејства (семејства во кои партнерите се од раздична етничка група, познати разговорно и како мешани бракови).

Фокус на наша анализа ќе бидат три модели на семејства: (1) вонбрачната заедница, како модел на семејство кој е сѐ почесто застапен во PCM; (2) хомосексуалната заедница, партнерска заедница која е најмалку видлива во јавниот простор на современото македонско општество и (3) мултиетничките семејства, кои не се целосно прифатени иако РСМ претставува мултикултурна и мултиконфесионална држава.

Вонбрачната заедница се дефинира како заедница во која живеат две лица кои се во партнерски (сексуални односи) без да стапат во брак (Nazio, 2008, 3). Во PCM дополнително се прецизира дека вонбрачната заедница претставува заедница на маж и жена која траела најмалку една година, при што тие ги уживаат истите права како и партнерите на брачните заедници и тоа во однос на правото на заштита од семејно насилство, право на имот кој е стекнат за време на траењето на заедницата и право на меѓусебно издржување (Закон за семејство, 2014). Зголемениот број на вонбрачни заедници е последица на повеќе процеси меѓу кои: општественото прифаќање на сексуалните односи пред бракот, недовербата во бракот како заедница, одложувањето на родителството, зголемениот број на разводи и вонбрачни деца, промената на партнерските односи и родовите улоги, како и еманципацијата на жените (Karraker, 2008). Овие промени и трендови ги следи и РС Македонија, во која, според последниот официја- 
лен попис на населението во 2002 година живееле 6.027 вонбрачни заедници (Државен завод за статистика на Република Македонија, 2004), бројка која веруваме дека е многу поголема денес. Истовремено, податоците укажуваат на постојан пораст на вонбрачните деца кои изминатата деценија претставуваат околу 11\% од вкупниот број на живородени деца во РСМ., а во 2018 година достигнале 12,1\% или 2.587 од вкупно 21.333 живородени деца (Државен завод за статистика на Република Северна Македонија, 2019). Денес, вонбрачните заедници се популарни кај младата популација, која не го отфрла целосно бракот, но претпочита да живее одредено време со партнерот или партнерката во трајна вонбрачна заедница или привремена „предбрачна заедница“ (Авировиќ, 2017).

Мултиетничките/мултирасните семејства претставуваат семејства чии родители се од раздична етничка, религиозна иди расна заедница. Иако РС Македонија претставува мултиетничка и мултиконфесионална држава сепак мешаните бракови сѐ уште не се целосно општествено прифатени особено кога станува збор за партнери од раздична религија. Како за хомосексуалните заедници така и за мултиетничките семејства немаме доволно статистички податоци кои би можеле да се анализираат и речиси сите истражувања на оваа тема имаат квалитативен карактер. И во овој случај, истражувањата посочуваат дека степенот на религиозност на дуѓето влијае на прифаќањето на овие семејства, особено доколку станува збор за брак помеѓу партнери кои се од раздична вера (Попоска, Стојановски, 2016).

Хомосексуалните заедници или заедници чии партнери се од ист пол немаат право на формално склучување брак во РС Македонија, истовремено овие заедници се предмет на дискриминација и не се целосно прифатени во нашето современо општество и за нивната бројка не постојат официјални податоци. Првата земја во Европа која ги легализираше истополовите бракови беше Холандија во 2001 година, а по неа следуваа уште 28 држави во светот, со раздични права во однос на посвојувањето деца (Oinonen, 2008). Со цел зголемување на правата и видливоста на припадниците на АГБТ заедницата, во 2019 година во РСМ се одржа првата парада на гордоста „Прајд Скопје“, која доби голема поддршка од активистите во регионот, странски амбасадори и политичари, но поради опасност од инциденти беше спроведено полициско обезбедување, а истовремено се одржуваше и паралелен марш за зачувување на традиционалните вредности. Досегашните истражувања посочуваат дека хомофобијата е присутна кај поредигиозните и традиционални општества и повозрасните луѓе за раздика од мдадите (Mitchell, Fries, 2016) и таа хипотеза беше обработена во нашето истражување прикажано во следниот дел на овој труд.

\section{Истражување за перцепцијата на нови модели на семејства во совре- меното македонско општество}

Официјалните статистички податоци за процентуалната застапеност на раздичните модели на семејства во современото македонско оп- 
штество се недоводни иди недостапни од повеќе причини. Една од нив е отсуствотото на попис во државата од 2002 година, кој ги опфаќа брачните и вонбрачните заедници. Во одредени случаи, како кај хомосексуалните заедници, е игнорирањето на нивното постоење од страна на општеството и институциите, додека за мултиетничките семејства имаме мал број истражувања на располагање. Оттаму, одлучивме да направиме квадитативно истражување кое ќе претходи на следно поголемо квантитативно истражување и се однесува на прифаќањето и перцепцијата на три нови модели на семејства: вонбрачни заедници, хомосексуални заедници и мултиетнички семејства, правејќи при тоа компарација на две раздични старосни групи. Нашата хипотеза беше дека постарите генерации помалку ги прифаќаат новите форми на семејства за раздика од помладите кои имаат поголема толеранција кон истите, додека втората претпоставка е дека хомосексуалните заедници се најмалку прифатени од страна на двете старосни групи, како резултат на големото ниво на хомофобија во нашата држава и регионот (Weiss, Bosia, 2013).

Нашето истражување беше спроведено од октомври до декември 2019 година во поголемите градови на РСМ: Скопје, Куманово, Дебар, Битола, Штип, Охрид, Кочани, Прилеп, Велес, при што најголем број испитаници се со потекло од Скопје, односно од вкупно 62 испитаници, 43 се од главниот град. Испитаниците беа поделени во две возрасни групи за да може да се направи компаративна анализа на нивните ставови, и тоа возрасна група бр. 1 од 45 до 60 години (28 испитаници) и возрасна група бр. 2 од 20 до 35 години (34 испитаници). Изборот на испитаници од урбана средина се должи поради фактот што моделите на семејства кои ги анализиравме не се сѐ уште прифатени во рурадните средини во РСМ., каде општествениот и семејниот притисок, како и стигмата се поизразени (Авировиќ, 2017). Начинот на испитување се вршеше со помош на структуриран прашалник кој се спроведуваше во живо или онлајн/телефонски во зависност од можностите за средба со испитаниците. Прашадникот се состои од девет теми со потпрашања со можност за слободен одговор, а во овој труд ќе бидат презентирани резултатите од делот посветен на нови модели на семејства, односно ставовите на испитаниците во врска со вонбрачните заедници, мултиетничките семејства и хомосексуалните заедници.

Испитаниците од првата група (45-60 години) изразија најмногу позитивни мислење за вонбрачните заедници. Имено, мнозинството испитаници (14) ги прифаќа овие заедници иди ги изедначува со брачните, бидејќи најчесто сметаат дека единствената раздика помеѓу нив е официјализирањето на врската („потпис на хартија“) преку граѓанска или верска брачна церемонија. Иако позитивно прифатени, сепак многумина изразија мислење дека овие заедници би било подобро да се трансформираат во брачни. Голем број испитаници (10) имаа негативен став кон вонбрачните заедници, најчесто без да го аргументираат своето мислење, но генерално одговорите се однесуваа на неискреноста на намерите на двајцата или ед- 
ниот партнер во таквата заедница. Останатите испитаници (4) изразија неутрален став кон вонбрачните заедници. Податоците на ова истражување се слични со оние на наше претходно квантитативно истражување од 2016 година за „Перцепцијата на младите (18 - 22 години) од Македонија за бракот разводот и вонбрачните заедници“ во кое повеќе од половина од испитаниците изјавија дека нивните родители (чија возраст одговара на испитаниците од првата старосна група), не би се согласиле тие да живеат во вонбрачна заедница (Avirovic, Radulovic, 2016).

На прашањето да го изразат и аргументираат своето мислење за мултиетничките семејства или мешаните бракови, мнозинството испитаници (19) имаше негативен став. Сепак, мора да напоменеме дека најчесто тие не ги отфрлаа овие заедници туку ги квалификуваа како „комплексни“, "подложни на осуди од околината", или со можност "да влијаат негативно на децата“. Често пати, испитаниците посочуваа дека кога станува збор за мултиетнички семејства би било подобро тие да бидат од иста вера бидејќи како што потенцираше една од нашите испитанички (50 години, од Скопје) „[...] во браковите во кои партнерите се по вера различни, секогаш едниот партнер мора да се потчини на верата на другиот“. Останатите испитаници имаа позитивно (5) или неутрално мислење (4) кон овие заедници. Со оглед на тоа дека РСМ е мултиетничка и мултиконфесионална држава, очекувавме повеќе позитивни одговори во однос на овој модел на семејство. Сепак, иако религиската толеранцијата, како и интеракцијата помеѓу раздичните етнички групи е зголемена во јавниот простор во последните години (Ristevska, Daskalovski, 2011), очигледно е дека кога станува збор за интерперсоналните, партнерските односи и приватната сфера, нашите граѓани имаат одредени задршки.

Резултатите од мислењата на првата група испитаници во врска со хомосексуалните заедници се слични на оние со мешаните бракови со 20 негативни ставови, 4 позитивни и 4 неутрални. Мнозинството испитаници не ги поддржува овие заедници, најчесто од верски побуди или бидејќи "природата не дозволува репродукцииј помеѓy лицза од ист пол" (испитаничка од Дебар, 45 години). Многумина од испитаниците го потенцираа мислењето дека хомосексуалните заедници не се "природна појава" и дека не би требало да имаат можност за одгледување деца. Дел од испитаниците, покрај тоа што не ги поддржуваат овие заедници, тие истите ги осудуваат.

Кога станува збор за одговорите на помладата група испитаници (20-35) години, одговорите не се раздикуваат драстично во компарација со оние на повозрасните испитаници. Имено, мнозинството (16) испитаници ги поддржува вонбрачните заедници и ги прифаќа како „нормални“, додека 10 испитаници сметаат дека доколку партнерите одлучиле да живеат заедно, тие би требало да се одлучат за брак, бидејќи вонбрачните заедници ги квалификуваат како „нестабилни“. Осум испитаници изразија неутрален став кон вонбрачните заедници. И овие податоци не беа изненадувачки и беа слични со претходно квантитативно истражување за вонбрач- 
ните заедници од 2017 година направено на брачни парови и парови кои живеат во вонбрачна заедница во РСМ. Имено, резултатите од тоа истражување посочија дека половина од испитаниците ја изедначуваа брачната и вонбрачната заедница (Авировиќ, 2017).

Мислењата за мешаните бракови се слични со оние на групата повозрасни испитаници. Мнозинството (14) не ги прифаќа, најчесто поради можноста овие семејства да се соочуваат со отфрдање од страна на општеството иди пак кога е во прашање раздична вероисповед. Сепак, голем дел од испитаниците (11) ги прифаќаат мултиетничките семејства и сметаат дека етничките и верските раздики не би требало да претставуваат пречка за среќата на партнерите. Осум испитаници изразија неутрален став кон овие семејства, односно ниту ги прифаќаат ниту ги осудуваат мешаните заедници, додека двајца испитаници не го изразија своето мислење. Иако потолерантни од групата повозрасни испитаници, сепак кога станува збор за брак и градење семејство, и помладите претпочитаат партнерите да бидат барем од иста религиска група, најчесто поради избегнување конфликти со семејствата или општествена стигма.

Во однос на хомосексуалните заедници мнозинството (17) испитаници не ги прифаќа истите, најчесто поради фактот дека кај истополовите заедници не може да се изврши репродуктивната функција, но и во случај на посвојување деца тие изразија негативен став, сметајќи дека тоа би претставувадо „нездрава средина“ за детето. Дури и оние (8) испитаници кои ги прифаќаат хомосексуалните заедници, сепак претпочитаат тоа да не се случи на нивните деца или пак да не им се дозволува посвојување деца. Останатите (9) испитаници изразија неутрален став кон овие заедници, односно ниту ги прифаќаат ниту ги осудуваат.

Според резудтатите од нашето квадитативно истражување нашата прва претпоставка дека повозрасните испитаници се помалку толерантни отколку помладите генерално не се потврди, бидејќ разликите во одговорите не беа значителни, особено кога станува збор за мултиетничките семејства и истоподовите заедници. Единствено се раздикуваат нивните ставови во врска со вонбрачните заедници, кои се повеќе прифатени од втората старосна група. Што се однесува на хомосексуалните заедници, хипотезата дека тие се најмалку прифатениот модел на семејство од страна на сите испитаници, таа се потврди, бидејќи повеќе од половина испитаници изразија негативно или неутрално мислење кон нив.

Резултатите за позитивното мислење за вонбрачниот модел на семејство беа исто така предвидени и се совпаѓаат со повеќе претходни истражувања кои ги наведовме погоре и кои укажуваат на тоа дека тие се најчесто општествено прифатени заедници во урбаните средини, одговараат на динамичниот живот на мдадите, а истовремено може да се преминат во брачни заедници со договор на партнерите. 


\section{Заклучок}

Индустриската револуција во Европа донесе низа општествени промени кои несомнено влијаеја на семејството, неговата структура, функции и односи помеѓу членовите на семејството. Индустријализацијата и урбанизацијата го дефинираа нуклеарното семејство, кое сѐ уште претставува доминантен модел на семејство во современото европско општество. По Втората светска војна, како резултат на еманципацијата на жените, ширењето на идеалите на хипи-движењето и феминистичките идеи, како и секуларизацијата на општествата и зголемената индивидуализација, покрај нуклеарното семејство имаме нови форми на семејства кои се раздикуваат по својата структура, а најзастапени се: реконструираните семејства, вонбрачните заедници, семејствата со еден родител, мултиетничките семејства, истополовите заедници и други.

Намалувањето на влијанието на заедницата и моралните стеги кои беа обележје на минатото доведе до поголемо прифаќање на раздични модели на семејства и заедници кои се перципираа како неприфатливи во традиционалните патријархални општества. Во РС Македонија како и во медитеранските земји во Европа новите форми на семејства се прифаќаат побавно отколку во Северна Европа, каде особено вонбрачните заедници се прифатени како алтернатива на бракот уште од 90-тите години на 20тиот век (Nazio, 2008, 15). Причините за раздичната семејна динамика на динијата север - југ се раздиките во семејните традиции, историското минато, но и раздичниот социокултурен контекст.

Изнесените резултати од нашето квалитативно истражување за перцепцијата на вонбрачните заедници, мултиетничките семејства и истополовите заедници на раздични возрасни групи испитаници од урбана средина во РС Македонија сугерираат дека и покрај тоа што бројот на овие заедници се зголемува во изминатите години, сепак ставовите на испитаниците се негативни особено кон мешаните бракови и хомосексуалните заедници. Во случајот на мултиетничките семејства, раздичната религиозна определба на партнерите се чини како најголем предизвик за партнерите паралелно со општествениот притисок и вдијанието на заедницата. Најмалку прифатени од двете групи испитаници беа истополовите заедници, резултат кој е одраз на изразената хомофобија во македонското општество, како кај повозрасните така и кај помладите генерации. Иако бројот на овие заедници исто така се зголемува, сепак тие остануваат невидливи во јавниот простор, токму поради изразената дискриминација. Единствената форма на семејство која е најчесто прифатена е вонбрачната заедница, во форма на алтернатива на бракот или пак како увертира на брачната, во форма на „предбрачна заедница“. Иако некои научници тврдат дека вонбрачната заедница се карактеризира со помали одговорности помеѓу партнерите, односно понизок степен на врзување, понизок наталитет и повисок ризик од разделба (Nazio, 2008), сепак таа е делумно прифатена во нашето општество особено од страна на помладите генерации. 
Со цел да се добијат подетални сознанија за перцепцијата на новите модели на семејства во РС Македонија, сметаме дека е потребно понатамошно продлабочено истражување со статистички релевантен примерок. Конечно, оваа тема е истовремено многу деликатна и комплексна и заслужува особено внимание и простор. Потребни се дополнителни истражувања за сите модели на семејства, но и едукација на младите за значењето на семејството, бракот, партнерските односи, родителството, семејните вредности и родовите улоги во семејството, со цел зголемување на свеста за значењето на семејството и намалување на предрасудите за раздичните семејни заедници.

\section{Питература:}

АвИРОВИќ, И. (2017). Дади предбрачните заедници го подобруваат бракот? Поглед кон семејната динамика во Македонија. Fourth International Scientific Conference: Social Change in the Global World - Proceedings. Штип: Унивезитет „Гоце Делчев“. 1099 -1113.

Avirovic, I., RAdulovic, M. (2016). Is De Facto Partnership a Threat to Marriage? A Case Study from Macedonia. European Journal for Social Sciences Education and Reseatcj (EJSER), European Center for Science Education and Research, January-April 2016 (Volume 6, Nr. 2).

ДРЖАВЕН ЗАВОД ЗА СТАТИСТИКА НА Р МАКЕДОНИЈА. (2004). Попис на населението, домаќинствата и становите 2002, Книга ХІІІ: Вкупно население, домаќинства и станови, според територијалната организација на Република Македонија. Скопје: Завод за статистика на Р Македонија.

ДРЖАВЕН ЗАВОД ЗА СТАТИСТИКА НА РЕПУБДИКА СЕВЕРНА МАКЕДОНИЈА. (2019). Соопитение: Наталитетот во Република Северна Македонија, 2018, по опитини. Скопје: Државен Завод за статистика на Република Северна Македонија. Преземено од:

http://www.stat.gov.mk/PrikaziSoopstenie.aspx?rbrtxt=8 (2.15.2020).

ЗАКОН ЗА СЕМЕЈСТВО, пречистен текст. (2014). Прв дел, ОПшти одредби, член 13. Преземено од:

http://www.mtsp.gov.mk/wbstorage/files/zakon_semejstvo_osnoven.pdf (10.5.2020).

KARRAKER, M.W. (2008). Global Families. New York: Pearson Education, Inc.

LASLETT, P., WALL, R. (1972). Household and family in past time. Cambridge: Cambridge University Press.

Мицковиќ, Д. (2008). Семејството во Европа XVI - XXI век, Скопје: Културна установа Блесок.

Mitchell, A., Fries, M. (2016). The Effect of Knowledge on Attitudes toward Homosexual Behavior. Race, Gender E Class , Vol. 23, No. 1-2, Race, Gen- 
der \& Class 2015 Conference (2016), pp. 183-202. Jean Ait Belkhir, Race, Gender \& Class Journal. Retrieved from:

https://www.jstor.org/stable/10.2307/26529198 (14.5.2020).

NAzIO, T. (2008). Cohabitation, Family and Society. New York: Routledge.

OINONEN, E. (2008). Families in Converging Europe, a Comparison of Forms, Structures and Ideals. Palgrave Macmillan.

ПОПОСКА, Ж., СТОЈАНОВСКИ, С. (2016). Истражувачки извештај - Влијание на стереотипите и етничката дистанца за појава на дискриминација, говор на омраза и криминал од омраза, Скопје: Мисија на ОБСЕ во Скопје. Достапно на https://www.osce.org/mk/skopje/295636?download=true (10.5.2020).

QuiLICI, M. (2010). Storia della paternità. Dal pater familias al mammo, Roma: Fazi editore.

RistevSKA, M. DASKALOVSKI, Z. (eds). (2011). One Decade after the Ohrid Framework Agreement: Lessons (to be) Learned from the Macedonian Experience. Skopje: Friedrich Ebert Stiftung and Center for Research and Policy Making Skopje. Retrieved from: http://www.crpm.org.mk/wp-content/uploads/2017/12/OneDecade.pdf (10.2.2020).

Wall, R., Hareven, T. K., Ehmer, J., Cerman, M. (eds). (2001). Family History Revisited, Comparative Perspectives, Newark: University of Delaware Press.

WEISS, M.L., BosIA, M.J. (eds.). (2013). Global Homophobia, States, Movements, and the Politics of Oppression. University of Illinois Press. Retrieved from: http://www.jstor.com/stable/10.5406/j.ctt3fh5hk.8 (14.5.2020). 